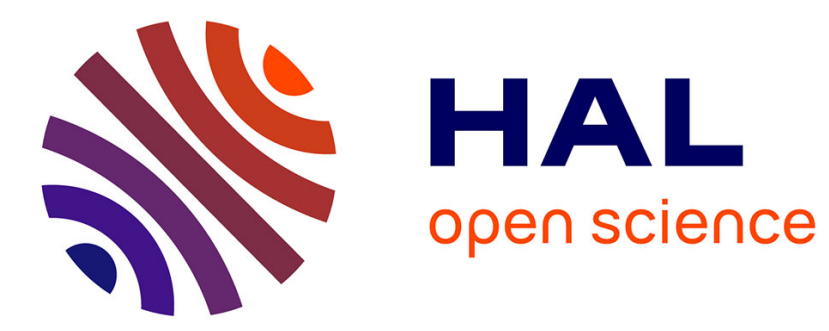

\title{
Food resources and diets of soil animals in a small area of Scots pine litter
}

Jean-François Ponge

\section{To cite this version:}

Jean-François Ponge. Food resources and diets of soil animals in a small area of Scots pine litter. Geoderma, 1991, 49 (1-2), pp.33-62. 10.1016/0016-7061(91)90090-G . hal-00506971

\section{HAL Id: hal-00506971 \\ https://hal.science/hal-00506971}

Submitted on 25 Oct 2010

HAL is a multi-disciplinary open access archive for the deposit and dissemination of scientific research documents, whether they are published or not. The documents may come from teaching and research institutions in France or abroad, or from public or private research centers.
L'archive ouverte pluridisciplinaire HAL, est destinée au dépôt et à la diffusion de documents scientifiques de niveau recherche, publiés ou non, émanant des établissements d'enseignement et de recherche français ou étrangers, des laboratoires publics ou privés. 


\title{
Food resources and diets of soil animals in a small area of Scots pine litter
}

\author{
J.F. Ponge \\ Museum National d'Histoire Naturelle, Laboratoire d'Ecologie Générale, 4 Avenue du Petit-Chateau,
}

F-91800 Brunoy, France

\section{ABSTRACT}

The fauna inhabiting a small area (ca. $5 \mathrm{~cm} \times 5 \mathrm{~cm}$ ) were investigated in a Scots pine stand. After microstratification of the litter layers in the field and fixation in $95 \%$ ethyl alcohol, invertebrates, mainly mesofauna, were sorted under a dissecting microscope and mounted or dissected in order to study their intestinal guts. Faeces were mounted or sectioned to obtain information about the activity of other invertebrate groups not represented in the sample and to follow the fate of plant and microbial material after defaecation occurred.

Plant material, mainly from moss, bracken, pine needles and bark, was extensively consumed by enchytraeid and lumbricid worms, sciarid larvae and phthiracarid mites. Fungal material was ingested by all groups, either in combination with plant material or alone (camisiid and oppiid mites, some species of Collembola, sciarid and chironomid larvae). Isotomid springtails and chironomid larvae appeared to consume faecal material. The choice and the degree of comminution and digestion of the material differed greatly from one group to another, but without any indication of resource sharing.

\section{INTRODUCTION}

The role of fauna in forest soils has been the subject of many investigations. Despite their low contribution to total soil metabolism (Macfadyen, 1963), invertebrates are known to influence microbial populations, and hence indirectly affect total metabolism, by regulating fungal growth (Warnock et al., 1982; Ulber, 1983; Gochenaur, 1987), disseminating fungal and bacterial propagules into new substrates (Visser et al., 1981) or reactivating senescent microbial colonies (Hanlon, 1981). The net effect of these activities appears to 
depend on the density of animals and conditions for the development of microflora (Wolters, 1988). The importance of soil fauna in the development of soil structure can be seen as channels and faecal deposits throughout the humus profile (Kubiëna, 1943, 1955; Zachariae, 1965; Bal, 1970; Babel, 1975; Bal, 1982; Kretzschmar, 1987).

Microscopic investigations in a small volume of soil (Ponge, 1984, 1985a,b, 1988, 1990, in prep.) helped us to understand some functional relationships between soil animals, soil microflora and the living and dead plant material in the top centimeters of a moder humus. Results for fauna are presented here, and the ecology and ecological effects of soil and litter invertebrates are discussed.

\section{MATERIAL AND METHODS}

A unique sample was taken in August 1981 from a $35 \mathrm{yr}$ old Scots pine (Pinus sylvestris L.) stand in the Orleans Forest (Loiret, France), which had not been thinned until the time of sampling. The ground flora mainly consisted of the moss Pseudoscleropodium purum (L.) and bracken (Pteridium aquilinum (L.). The humus was of the moder type (Ponge, 1984). Microstratification of the surface horizons was made in the field on an area of ca. $5 \mathrm{~cm} \times 5 \mathrm{~cm}$. Only the first three sub-layers were intensively studied, $\mathrm{L}_{1}$ (entire brown needles, living mosses), $\mathrm{L}_{2}$ (entire black needles, dead mosses) and $\mathrm{F}_{1}$ (fragmented needles, roots, fungi and animal faeces). These layers corresponded to the $\mathrm{L}_{\mathrm{n}}, \mathrm{L}_{\mathrm{v}}$ and $\mathrm{F}_{\mathrm{r}}$ sub-Iayers (sensu Babel, 1971). After dissecting the plant material out of the woodland floor it was immediately fixed in $95 \%$ ethyl alcohol. In the laboratory, plant fragments, animals and faeces were sorted under a dissecting microscope and appropriate techniques were used for their study (Ponge, 1984). Most animals were mounted intact under a cover slide into chlorallactophenol $\left(25 \mathrm{~cm}^{3}\right.$ lactic acid $+50 \mathrm{~g}$ chloral hydrate $+25 \mathrm{~cm}^{3}$ phenol). Oribatid mites, which had a thicker tegument, were dissected and the cuticles discarded, but the small Oppia species were mounted whole. The volume of each individual was estimated by means of three measurements [length, width and thickness, see Ponge (1984) for further details].

All animal groups (mainly mesofauna and macrofauna) present at the time of sampling were collected. Microfauna (protozoans, nematodes, rotifers) were poorly recovered, as a consequence of their small size and transparency. Animals that were living inside plant material (phthiracarid larvae, nematodes, amoebae) were also underinvestigated. 
Unless otherwise stated, phase contrast microscopy was used to study gut contents. The presence of intact cytoplasm in the ingested cells was detected through its opacity (Frankland, 1974).

\section{VERTICAL DISTRIBUTION OF INVERTEBRATES}

Figure 1 indicates the density and body volume of the five main mesofaunal groups recorded in the three litter layers. The sampled surface was approximately $0.25 \mathrm{dm}^{2}$. The volume estimate which was used for the animals was $V_{\mathrm{I}}$ (Ponge, 1984), i.e., the upper estimate (animals were compared to a parallelepipedic volume having the same dimensions). The true volume falls within a range from $0.25 V_{\mathrm{I}}$ to $V_{\mathrm{I}}$.

A marked increase in total density and bio-volume of fauna from the $\mathrm{L}$ to the $\mathrm{F}$ layers was observed. This was mainly due to enchytraeid worms, mites and springtails (Collembola). Unlike enchytreids whose numbers regularly increased from $L_{1}$, to $F_{1}$, oribatid mites decreased from $L_{1}$ to $L_{2}$ then increased to $F_{1}$, Collembola were numerous only in the $\mathrm{F}_{1}$ layer. Within each group, the species composition of the layers differed except for enchytraeids represented by the single species Cognettia sphagnetorum (Vejd.). Oribatids were dominated by camisiid species in the L layers and by phthiracarid species in the $\mathrm{F}_{1}$ layer (Ponge, 1984, 1985a, 1988). Springtails were dominated by isotomid species in all layers. Diptera larvae were dominated by a cecidomyid species in the $\mathrm{L}_{1}$ layer, and by a sciarid species in the two other layers.

The groups which played a prominent role in the decomposition process of plant material were enchytraeids, phthiracarid mites, sciarid larvae and epigeous earthworms (Ponge, in prep.). The three former groups actively tunnelled through pine needles and pieces of bark (Figs. 2 and 3), and the earthworms crushed the needles after ingestion of entire fragments.

\section{FOOD RESOURCES AND THEIR FATE IN ANIMAL GUTS AND FAECES}

Table 1 summarizes ingestion of the different food resources by the observed animal groups, and their fate in the guts or faeces. Digestion or transformation refers to cell walls, since cytoplasm was always digested. Observations of intact plant and fungal material were made to facilitate the identification of material in guts and faeces. The treatise on plant anatomy by Esau (1965) was used as a reference for nomenclature of higher plant 
tissues.

Plant tissues from pine needles were identified in the guts through the presence of lignified tissues such as tracheids from protoxylem (Fig. 4) and metaxylem. The transfusion tissue of pine was characterized by an accumulation of bordered pits (Fig. 5). Other hard structures, such as guard cells of stomata and epidermis, were used to identify material derived from pine needles. Pine needles were ingested by all groups except springtails and oribatid mites other than phthiracarids. Digestion occurred only in the intestine of sciarid larvae. In the postcolon of phthiracarid mites the plant cell walls were observed becoming brownish and their structure amorphous, especially at the center of the food pellets. The feeding activities of other animal groups was followed through their faecal pellets (Figs. 6-8).

The moss Pseudoscleropodium purum was consumed by animals both in the living state $\left(\mathrm{L}_{1}\right.$ layer) and after invasion by fungi ( $F_{1}$ layer). Thus, in the $L_{2}$ layer, where moss was dead but relatively free of fungal hyphae, it was very rarely encountered in animal guts and faeces.

Pine resin was ingested by enchytraeids (Fig. 9), which were often found between bark and wood in fallen twigs and branches. This material was never observed in any other group and the degree to which the worms deliberately ingested resin, and were able to digest it, is unknown.

Pollen grains from pine were commonly encountered in the food bolus of many enchytraeids (Figs. 10 and 11) and Sciarids (Fig. 12) and in earthworm faeces. Lysis of the more resistant surface layers of pollen grains was observed in the gut of enchytraeid worms. In every case, pollen grains were ingested mixed with many other materials, since this food resource was finely dispersed throughout the litter.

Soil fungi were the resource the most widely selected by soil animals. Fungal material, predominantly hyphae, were observed in the guts of all observed animals except starved (moulting) individuals. Hyaline hyphae were the most abundant form in this soil volume. Most of them were produced by a mycorrhizal basidiomycete, belonging probably to the genus Hyphodontia (Ponge, 1988). It also colonized dead pine wood in our sample. Hyphae of this fungus were observed to be connected to the pine root system (orange-brown coralloid mycorrhizae) and to penetrate the litter (Ponge, 1990). These hyphae were found in the guts of enchytraeid worms, where they appeared to be more or less digested (Fig. 13). Hyphae covered with oxalate crystals were egested as compacted masses once the chitinous walls had been fully digested. In oribatid mites, hyaline hyphae of Hyphodontia were observed in the genus Oppia, where digestion commonly occurred, and in several other 
species where digestion did, or did not, occur (Ponge, 1988). Some species of Collembola fed on this fungus, such as Pseudosinella terricola Gisin, 1967 (Fig. 14), Willemia anophthalma Börner, 1901 and Pogonognathellus flavescens (Tullberg, 1871). In every case digestion occurred, except for the oxalate crystals. Sciarid larvae did not appear to be able to digest hyaline fungal walls, since these hyphae were always present without any change in their appearance (Fig. 15), but the opacity of the cytoplasm had disappeared (when observed in phase contrast microscopy), indicating that only the cell contents were used by these animals. Hyaline hyphae were also ingested by members of the macrofauna, together with plant material, but unfortunately the feeding behaviour of these animals was observed only through their faeces. Since it was virtually impossible to discriminate between fungi colonizing faecal masses and those ingested with the original food material we could not reach a conclusion on this point.

Dematiaceous (melanine stained) fungi were present mainly in the form of the dark mycelium of the sterile mycorrhizal ascomycete Cenococcum geophilum Fr. A broad spectrum of animal species was also feeding on this fungus (as specialized feeders or not), but, contrary to the aforementioned hyaline basidiomycete, the digestion of the hyphal walls of this fungus seemed difficult or even quite impossible for most groups. Dematiaceous hyphal walls remained intact in enchytraeid worms (Figs. 16, 13: compare to hyaline hyphae). In some cases, some signs of attack were visible, such as small holes in the thick walls of this fungus (Fig. 17), but this was probably due to the action of bacteria or amoebae prior to ingestion by the animal. More pronounced features were also observed, which might be due to the action of gut enzymes. In some other cases, where decay was still more pronounced, we hypothesize that the dematiaceous material had been already ingested by another animal and was present as faeces in the food bolus of enchytraeids. Dematiaceous hyphae and spores were present in the food bolus of oribatid mites, mainly camisiid species such as Platynothrus peltifer (Koch, 1839) and Nothrus sylvestris (Koch, 1839) and were also observed in faecal pellets (Fig. 18). Observation of faeces indicated that some transformation in plant tissue structure occurred, especially at the centre of the pellets, but this was not observed inside animal guts.

Filamentous cyanobacteria were found in enchytreid guts. Digestion was followed by comparing several parts of the same animal intestine: cells were separated then emptied (Fig. 19), with the cellulosic walls remaining untouched.

Unicellular algae were often found in the guts of enchytraeids (Fig. 20). Viability of the cells was recognized by opacity of their cytoplasm when observed in phase contrast. The presence of intact cells inside the 
intestine indicated that digestion of algae seemed to be somewhat difficult. Nevertheless digestion occurred with the help of intestinal microflora (Fig. 21): cells were (1) coated with bacteria, then (2) their cytoplasm disappeared, and (3) they collapsed. One species of Collembola, Lepidocyrtus lanuginosus (Gmelin, 1788) seemed to digest algae more easily, since no opacity was found in the cells (Fig. 22). Some cell walls were seen to be partially digested but, unfortunately, the few animals collected of this species made it impossible to conclude that digestion of the walls was always occurring. In this collembolan, death of the algae was only due to the action of the animal: no associated bacteria were found in the intestine of Collembola, contrary to other animal groups as will be seen below (and confirmed in transmission electron microscopy by Saur and Ponge, 1988).

Bacteria were present in a lot of plant fragments that were ingested both by macrofauna and mesofauna (especially pine needles in the $\mathrm{L}_{2}$ layer, Ponge, 1985a), but in this case their fate was not easy to discern. Nevertheless it must be noticed that the food bolus of the collembolan species Megalothorax minimus (Willem, 1900) was always made of bacteria mixed with minute fungal and mineral particles (Fig. 23).

Faecal material was seemingly the main food of some species of Collembola belonging to the same family (Isotomidae), namely Folsomia manolachei Bagnall, 1839 ( = F. nana), Parisotoma notabilis (Schtiffer, 1896) ( = Isotoma notabilis) and Isotomiella minor (Schtiffer, 1896). Although the shape of ingested faeces had been lost, due to comminution by buccal parts, the ingested food is a mixture of different materials, always halfdigested and mixed with bacteria. When no comminution took place in the food bolus, as was the case in enchyraeid worms, entire faeces were recovered in the guts, especially the strongly compacted oribatid faeces (Fig. 24). This was also observed inside earthworm faeces (Ponge, 1988). Tunnelling of epigeic earthworm faeces composed of organic matter by phthiracarid mites (Rhysotritia duplicata) was also observed in the $\mathrm{F}_{1}$ layer.

Animal remains on the contrary were commonly encountered, especially in enchytraeid guts. These were most often tests of testate amoebae. Digestion of the test of Trinema sp. or Phryganella acropodia (Hertwig and Lesser, 1874) Hopkinson, 1909, was observed. The case of P. acropodia deserved attention, because the test of this species is mainly made of aggregated mineral particles. Careful examination of all clusters of mineral particles found in the intestinal guts of enchytraeids suggested that they were derived from the disintegration of tests of this very common species. 


\section{INTESTINAL MICROFLORA}

Association with bacteria presumed to be living in the intestine was commonly observed in all saprophagous groups, except Collembola. Intestinal microflora might be directly observed as bacterial clouds distinct from the food bolus (except in Fig. 21 where algal cells were in contact with them), without any lysis symptom, and was present even in starved animals. These bacteria were commonly observed in nematoda, rotifera, enchytraeidae, sciarid larvae, oribatid mites (Fig. 25) but were never observed in springtails.

\section{SPECIFICITY IN FOOD DIETS}

Observation of a great number of soil animals living in the same environment supported the idea that very few species were specialized feeders and that the bulk of food resources were consumed without any discrimination. This held especially true for oligochaeta, i.e., enchytraeid and lumbricid species. Nevertheless this view must not be taken as the negation of choice by soil animals.

The epigeous worm Dendrobaena octaedra (Savigny, 1826) was probably the only lumbricid species present in the sample examined. These animals did not show any choice in their food diet, as could be judged from their faecal pellets, and gut contents reflect undiscriminating consumption of the material present in the microhabitat occupied by the worm.

The animal species that had been more extensively studied here is the enchytreid worm Cognettia sphagnetorum (128 individuals). These animals showed differences in the ingestion of moss leaves between the three layers investigated: green leaves were consumed in the $\mathrm{L}_{1}$ layer, dead but uncolonized leaves were ignored in the $L_{2}$ layer, and leaves colonized by fungi were consumed in the $F_{1}$ layer (Ponge 1984, 1985a, 1988). In addition, filamentous cyanobacteria ( = blue-green "algae"), testate amoebae, pollen grains and resin were more commonly found in the gut of these animals. The absence of pine needles in the animals present in the $\mathrm{L}_{1}$ layer was probably due to their early stage of fungal decomposition (especially the strong cuticle which impeded penetration). This was also the case for the sc1erotia of the fungus Cenococcum geophilum, which were certainly too hard structures. With these exceptions all materials available to these animals were actively ingested. 
Sciarid larvae (22 individuals) actively consumed moss leaves in the $\mathrm{L}_{1}$ layer, fungal hyphae in the $\mathrm{L}_{2}$ layer and pine needles in the $\mathrm{F}_{1}$ layer. We cannot prove that the same sciarid species was involved but this was probably true, since the individuals seemed to be morphologically identical and belonged to the same colonial group.

Collembola were represented by several groups of species, with distinct food diets. Isotomid species (Folsomia manolachei, 30 ind.; Parisotoma notabilis, 24 ind.; Isotomiella minor, 5 ind.) seemed to be charaeterized in our litter sample by their coprophagy. It is difficult to say that this diet was specialized, since the composition of the pellets so ingested was highly variable, but from a behavioural point of view, these animals might be classified as specialized feeders. Pseudosinella terricola (8 ind.) and Willemia anophthalma (8 ind.) were strictly fungal feeders and the degree of specialization of the second species was higher: this animal ingested only the hyaline hyphae of the basidiomycete fungus Hyphodontia. The other species of Collembola were in too low numbers to ascertain their food diet.

Oribatid mites, whatever the taxonomie group they belonged to, were the most specialized animals. Phthiracarids (Rhysotritia duplicata, 14 ind.; Phthiracarus sp., 10 ind.) ate only pine material (needles and bark), tunnelling within plant tissues. Nevertheless it must be noticed that adults seemed to have less specialized requirements, since some fungal material (hyphae of mycorrhizal fungi in the present case) was eaten to a little extent. Oppiids [Oppiella nova (Oudemans, 1902), 7 ind.; Oppia subpectinata (Oudemans, 1901), 9 ind.; undetermined nymphs, 3 ind.] fed only on fungal hyphae, the ratio of hyaline versus dematiaceous hyphae varying with the size of the animals (dematiaceous hyphae of the mycorrhizal Cenococcum geophilum needed animals with stronger buccal pieces to break them off). Camisiids sensu lato [Platynothrus peltifer (Koch, 1839), 25 ind.; Nothrus sylvestris (Koch, 1839), 5 ind.] seemed to be specialized in our sample on the mycorrhizal $C$. geophilum. It is worthy to note that, although the first species ate only mycelia in the $\mathrm{L}_{1}$ layer (Ponge, 1984), the second one preferred the mycorrhizae formed by the same fungus in the $\mathrm{F}_{1}$ layer, ingesting also a small quantity of some root tissues (Ponge, 1988).

If we wanted to c1assify the different groups investigated according to their degree of specialization on food resources, we could obtain the following series (groups with too few data have been excluded):

Lumbricidae $<$ Enchytraeidae $<$ Sciaridae $<$ Collembola $<$ Oribatida 


\section{DISCUSSION}

A great deal of work has already been done on the feeding habits of soil animals. Most conclusive studies concerned only one taxonomic group or even one single species. The works of Zachariae (1985) and Bal $(1970,1982)$ were nevertheless closely related to the aim of the present study. Both of these scientists used thin slides of the upper horizons of forest soil to study trophic relationships that occurred during the decomposition of leaf litter. As was done in the present study, they attempted to reconstruct a dynamic process from instantaneous photography. Unfortunately the optic properties of the hard resins used to embed soil profiles were so questionable that observation could only be made at the lowest magnification of the light microscope. Other shortcomings were the absence of fauna in the studied profiles, due both to the process of desiccation and to the fact that on a given section the probability to find animals was very feable. Consequently animal feeding activities were traced only through their excrements, thus giving no results on digestive processes.

\section{Enchytraeid worms}

In the present study, enchytreid worms were the more thoroughly investigated group (because it was the more abundant at the time of sampling, 129 ind.), more precisely the acidophilic species Cognettia sphagnetorum. In the aforementioned work of Zachariae (1965), Enchytraeidae were not given a decisive role in the transformation of beech litter, and their feeding habits were interpreted as mainly coprophagous. In the work of Bal they were quite absent (Bal, 1970) or considered as negligible (Bal, 1982). This was also the case in Jacot (1939)'s observations on spruce and fir litter. We cannot dispute on these points, but our own experience in temperate forests raises doubts to the contention that enchytraeid worms do not play a key role in the comminution of leaf litter. The most conclusive work on the feeding habits and digestion abilities of enchytraeids (also C. sphagnetorum) is the study made by Latter (1977), Standen and Latter (1977) and Latter and Howson (1978). Latter and co-workers proved, both by field and laboratory experiments and observation of intestinal guts, that this species thrived on leaf litter (Rubus, Eriophorum or Calluna), and that leaf tissues were consumed and finely comminuted. Disagreement with our own observations was only with the respective fate of fungal and plant cell walls. In the present study we did not register any significant change in the appearance of plant cell walls, although crushing was pronounced. On the contrary, hyaline fungal walls were always partially digested. Comparison with sciarid larvae, for instance, allowed us to say that pine cell walls did not seem 
strongly affected by their passage through enchytraeid intestines, apart from their comminution (Ponge, 1988). Observation by light microscopy of the disintegration of cellulosic walls is difficult, due to their high transparency, but use of phase contrast helped to detect changes in refringency that might be related to changes in the cristalline structure of cellulose. Observations by light microscopy on the collembolan Paratullbergia callipygos (Börner, 1902) ( = Tullbergia callipygos) suggested that this species was able to dissolve cellulose to some extent. This was confirmed by transmission electron microscopy (Saur and Ponge, 1988). Concerning the fungal cell walls and their fate, no distinction was made between hyaline and dematiaceous fungi in Latter's studies, and we showed that only hyaline fungal walls were transformed in the intestine of Cognettia sphagnetorum. Ultrastructural studies on the enchytraeid worm Fridericia striata (Levinsen, 1884) (Toutain et al., 1982), fed on aspen leaves, concluded that plant cell walls were little affected in its gut (apart from some changes in the microfibrillar arrangement), contrary to fungal walls that were partly destroyed. Oxalate crystals that covered the hyphae of Hyphodontia did not seem to be dissolved in the gut of C. sphagnetorum. Thus these animals probably do not take a great part in the cycling of $\mathrm{Ca}$ through fungus-animal food chains, in contrast to what has been claimed by Cromack et al. (1977) for most soil animals.

Concerning the feeding behaviour of C. sphagnetorum, we observed the tunnelling activity of this species in pine needles, similar to the same behaviour inside the cylindrical leaves of the cotton grass (Latter and Howson, 1978). Penetration between bark and wood (phloem part) of dead pine branches was similarly recorded by these authors on heather woody stems. It must be noticed that the deposition of faecal pellets at the inside of the tunnelled needles was rarely observed, contrary to phthiracarid mites. Exception is in the $\mathrm{L}_{1}$ layer, where desiccation probably delayed animals escaping from the needles.

Intestinal microflora was commonly observed, with several morphological types often occurring together in the same intestine (but in distinctive metameres, Ponge, 1985a).

\section{Oribatid mites}

Oribatid mites were the second most abundant group (116 ind.). Rhysotritia duplicata (14 ind.) and Phthiracarus sp. (10 ind.) fed on dead plant tissues. They tunnelled pine needles, bark and faeces of epigeous earthworms and deposited their own faecal pellets inside the so-formed cavities. Tunnelling activity of phthiracarid mites inside litter debris has been recorded time and again (Jacot, 1939; Kubiëna, 1943, 1953; 
Handley, 1954; Kubiëna, 1955; Kendrick and Burges, 1962; Zachariae, 1965; Bal, 1970; Babel, 1975; Rusek, 1975; Kubikova and Rusek, 1976; Toutain, 1981; Bal, 1982) and therefore nothing needs to be added about the importance of these animals in the mechanical reduction of plant litter. We observed that pine needles were not penetrated by these animals until they reached the $F_{1}$ layer, contrary to the enchytraeid worms, tunnelling by them having been observed as early as the $\mathrm{L}_{1}$ layer. The question is whether phthiracarid mites were unable to feed on fresher needles or not, compared to enchyraeid worms. Jacot (1939) indicated that coniferous needles needed to be softened by fungi before any penetration by mites occurred. In the field study made by Kendrick and Burges (1962) on Pinus sylvestris litter, needles were not attacked by oribatid mites (presumably phthiracarid species) until the " $\mathrm{F}_{1}$ " layer, which corresponded in fact to our $\mathrm{L}_{2}$ layer. The laboratory study by Hayes (1963) on the coniferous species (including Scots pine) and three phthiracarid species concluded that needles needed to achieve a particular stage of fungal decomposition in order to be actively consumed by these animals. Thus our results did not agree exactly with other studies, although intense fungal penetration of the needles was considered by these authors as a prerequisite for penetration by phthiracrid mites. This discrepancy might be partly explained by the fact that our observations took place on a sample collected in August. This was the time of intense activity of enchytraeid worms, given the high level of their population density, probably due to rainy and overcast condition of the weather in the summer of 1981 . Summer was recorded as a period of intense vegetative multiplication of Cognettia sphagnetorum (Springett, 1970). Reproduction of phthiracarid species (Rhysotritia duplicata and Phthiracarus) was also effective at the time of sampling (presence of larval instars of the two species and eggs of the first), but not at the same rate as Enchytraeidae and they were probably more evenly distributed over the year: traces of phthiracarid activity (pellet deposition) were found in a lot of needles that were no longer inhabited by these animals. Thus we could say that enchytraeid activity was contemporary and phthiracarid activity rather a remnant of a past one at the time of sampling. Pine needles that were incorporated into the L layers might not have been on the ground long enough to be significantly colonized by phthiracarids. Other species may be classified as mycophagous or "microphytophagous" in the sense of Schuster (in Luxton, 1972). The distinction between plant feeder species (phthiracarids) and fungal feeders (other species, except perhaps Suctobelba which seemed to ingest a fluid food) in our sample corresponded roughly to what was known from the literature on oribatid food diets. Nevertheless, some species considered as "panphytophagous" (plant-fungal feeders) in other sites, were here strictly or mainly fungal feeders. Platynothrus peltifer (25 ind.) was found to eat exclusively the hyphae of the dematiaceous mycorrhizal Cenococcum geophilum in the $\mathrm{L}_{1}$ layer (Ponge, 1984) and faecal material containing the same fungus in the $\mathrm{L}_{2}$ 
layer (Ponge, 1985a). In the literature, this species was known to eat both plant and fungal material (Hartenstein, 1962a; Pande and Berthet, 1973; Anderson, 1975; Behan-Pelletier and Hill, 1983). Nothrus sylvestris (5 ind.) was interpreted as a root-fungal feeder (black mycorrhizae of C. geophilum), but mainly browsing the fungal mantle (Ponge, 1988). This species was generally considered as a plant-fungal feeder (Luxton, 1972; Pande and Berthet, 1973; Hågvar and Kjøndal, 1981; Behan-Pelletier and Hill, 1983), with plant feeding dominating. Other species, like Oribatula tibialis (Nicolet, 1855) (5 ind.) and Nanhermannia nanus (Nicolet, 1855) (5 ind.) ate a mixture of the two main mycorhizal fungi present in the studied sample (Ponge, 1988), but were considered as plant-fungal feeders by other authors (Pande and Berthet, 1973; Hågvar and Kjøndal, 1981; Behan-Pelletier and Hill, 1983). Perhaps pine needles were especially repellent for these species in our study site, nevertheless it must be remembered that Pande and Berthet (1973) and Hartenstein (1962a) worked also in pine stands. We prefer to suggest that the so-called plant-fungal feeder species favoured fungi which were far in excess of faunal requirements in the volume under study. Pine needles might perhaps be ingested in other times or in other places when preferred a food was not available, in contrast to phthiracarid mites which seemed to eat only plant material. Good agreement with other studies was found only with oppiid species (Oppia subpectinata, 9 ind.; Oppiella nova, 7 ind.), which were considered as pure fungal feeders (Hartenstein, 1962a; Haq, 1981), as in our observations, but it must be remembered that these small species seemed to choose hyaline hyphae rather than dematiaceous ones, probably because of the toughness of the latter.

Food partitioning between co-existing species was studied by Mitchell and Parkinson (1976). They found that differences in habitats between species were reflected in their gut contents throughout the year, both qualitatively and quantitatively. Microcosm experiments of Anderson (1978) on two related species demonstrated that at high densities habitat specialization was influenced by the presence of a competing species and that gut contents were largely determined by habitats. From our results, several facts may be ascertained. In this small soil volume, we were sure that differences between species in habitat and food were determined by environmental constraints and food preferences and not by differences in food availability. The exception was when food availability was influenced by micro-environment factors, for instance an animal physiologically unable to live in the $\mathrm{L}$ layers might not consume living mosses. In the $\mathrm{L}_{1}$ layer, where plant material (mainly pine needles and moss leaves) and fungal material were co-existing, Platynothrus peltifer was found to eat only dematiaceous hyphae although this species was known to consume also plant material, including pine needles (see above). We may suppose either that pine needles and moss leaves were not in a good decay state or that 
these fungi (presumably Cenococcum geophilum) were better liked. In the $\mathrm{L}_{2}$ layer, a few millimetres below, the same mite species was poorly present and apparently ate only the same fungus. In the $\mathrm{F}_{1}$ layer this mite was absent, although this was the place where C. geophilum was well developed and decaying pine and moss material were present. Thus we may tentatively suppose that the mite had (at the time of sampling) moved from the $F_{1}$ layer and was thus forced to feed in an environment where fungi were undoubtedly preferred to fresh plant material. Allelopathy (from enchytraeid worms for instance, with a higher bio-volume) might account for this. In the $\mathrm{F}_{1}$ layer, where most faunal species were present (except Platynothrus peltifer), food partitioning was evident between phthiracarid species, which fed only on plant material, and fungal-feeding species. Some oppiid species were seen only to ingest hyaline fungi. In this case, buccal anatomy and size of the animals were probably the main factors responsible for the observed segregation, but food niches for both plant-feeding and fungal-feeding species would be overlapping.

The fate of the materials ingested by oribatid mites was followed to some extent. Unfortunately, there is no conclusive study on this problem in the literature. Plant cell walls seemed to be highly transformed in phthiracarid species, especially during the transit time in the post-colon, where they lose their refrigency and sharp contour and became brownish. Ultrastructural studies would be needed to study these cellulosic and lignocellulosic walls at the fibrillar level. Fungal walls without melanin were destroyed, except in Nothrus sylvestris (Ponge, 1988). Oxalate crystals seemed to be dissolved together with the fungal walls, in contrast to enchytraeid worms. Disintegration of dematiaceous walls was observed in the gut of $N$. sylvestris and inside faecal pellets of the other fungal feeding species (Ponge, 1985a), but this was not observed in any other group.

Presence of an intestinal microflora was commonly observed in Platynothrus peltifer and Rhysotritia duplicata, where the same morphological strain seemed to be present in each of these two species, but appeared to be quite absent in Nothrus sylvestris and Phthiracarus sp. In the literature, associated bacteria were reported from numerous oribatid species (Hartenstein, 1962b; Dinsdale, 1974; Stefaniak and Seniczak, 1983) and the latter showed selection of associated bacteria and actinomycetes was strongly related to the feeding habits of the oribatid species.

\section{Collembola}

Feeding habits of springtails have been intensively studied, but several of our species are uncommon 
(acidophilic species, Ponge, 1980, 1983) and have not been investigated by other scientists. The present study showed that three common isotomid species (Folsomia manolachei, Parisotoma notabilis and Isotomiella minor) seemed to be mainly coprophagous, contrasting with mycophagous species such as Willemia anophthalma and Pseudosinella terricola. Comparison with other studies is rather difficult for these species, since faecal material was mostly overlooked by authors and in the best cases only described as "unidentifiable" (Poole, 1959; Gilmore and Raffensperger, 1970), "humus" (Knight and Angel, 1967; Gilmore and Raffensperger, 1970) or “amorphous” material (Knight and Angel, 1967; Bödvarsson, 1970; Marshall, 1978; Hågvar and Kjøndal, 1981). Nevertheless several authors assumed that this material had undergone previous digestion (Poole, 1959; Knight and Angel, 1967). The most important fact in determining the faecal origin of ingested material was the mixture of distinct strongly decayed material (mainly plant and fungal), associated with bacteria dispersed in the food bolus. Intestinal microflora when present (in other animal groups) were always observed as monospecific clouds of bacteria which were never dispersed in the food bolus.

Food specialization has been studied by some authors. Most of these works indicated that coexisting species exhibited differences in resource utilization but with tremendous overlapping between their respective food spectra. MacMillan and Healey (1971) pointed out the fact that some closely related species (here belonging to the genus Onychiurus) did not exhibit significant differences in their feeding habits, contrary to what was expected. The work of Bengtsson et al. (1988) demonstrated that these animals were influenced by smell in their choice of food, but their choice was different for animals reared on agar plates to those reared on soil contaminated with known fungal species. Hassall et al. (1983) observed that the vertical migration of one Onychiurus species into freshly remoistened litter was strongly influenced by microbial colonization of the decaying leaves. Feeding preferences were measured by Shaw (1988) with a great care in the statistical treatment: there was undoubtedly a constant hierarchy between the different fungal strains to be tested, but some ranks were not consistent with mortality results, indicating that the animals did not always feed on the most suitable fungal species. Verhoef et al. (1988) reared two sympatric species on algal, fungal and mixed diets and compared their growth and fecundity. They found that the most suitable diets were not necessarily those that were used by field animals. In laboratory experiments, Ponge and Charpentié (1981) concluded that spores were always preferred to hyphae in cultural tests of Pseudosinella alba fed with known species of fungi, although spores were rarely found in the gut contents of field animals. Vegter (1983) compared field and cultural observations and concluded that food specialization between co-existing species was mainly a reflection of 
differences in their micro-habitats. Such a conclusion was also supported by the work of Saur and Ponge (1988) where the proportion of different foods in the gut contents were shown to be dependent both on season and on vertical distribution of individuals of the same species. Our own observations showed in addition that food preferences existed between species or groups of species living in the same micro-habitat. The fungal content of Pseudosinella terricola and Willemia anophthalma guts compared to the algal content of Lepidocyrtus lanuginosus and to the faecal content in the three isotomid species was not a consequence of differences in their micro-habitats. Nevertheless it must not be argued that each Collembola species living in the same micro-habitat is specialized in its food habits. Observations on the three related isotomid species Folsomia manolachei, Parisotoma notabilis and Isotomiella minor showed that no food specialization existed between them in the studied sample. From the literature and the present study we must recognize that no general law currently explains or predicts soil food webs, apart the minimal evidence that food webs are the convergence point of resources and feeding preferences of animals that are present in a given place at a given time. Since choices change with the food resources available to the animals, no model can explain changes in the present state of our knowledge. Nevertheless it must be remembered that provided the scale of observation is sufficiently reduced, most significant trends are quite easy to perceive, although not applicable in samples some distance away.

Observations on the fate of ingested materials were made by a few authors with the help of transmission electron microscopy (Kilbertus and Vannier, 1979, 1981; Saur and Ponge, 1988). They did not correspond to our species, so unfortunately no comparison could be made with our results. Nevertheless it must be noticed that soil bacteria may constitute a food for Collembola (Saur and Ponge, 1988), as is probably the case in coprophagous and geophagous species, and that intestinal microflora were never observed in empty guts (Kilbertus and Vannier, 1981; Saur and Ponge, 1988), strengthening the idea that Collembola do not digest with the help of associated bacteria or actinomycetes.

\section{Sciarid larvae}

The most interesting feature was the succession of dominant materials which were observed in the gut contents of animals found from the surface to the deeper regions of the studied profile. Moss leaves (ingested in a green state) were replaced by fungal hyphae from the $\mathrm{L}_{1}$ to the $\mathrm{L}_{2}$ layer, then by plant tissues (coming from pine needles) in the $F_{1}$ layer. This trend paralleled similar features observed in enchytraeid worms (see above), 
except that pine needles were ingested by Enchytraeidae at an earlier stage of decomposition and that consequently there was not a so sharp boundary between the food diets observed in the three sub-layers. Other differences with enchytraeid worms were that fungal walls, even when hyaline, were never observed to be digested by sciarid larvae. On the contrary, sciarid larvae (at least the single unidentified species which was present in our sample) seemed to be able to digest cellulose, which was not the case for the enchytraeid Cognettia sphagnetorum. Studies on feeding habits of sciarid species are scarce. The observations of Healey and Russel-Smith (1971) and Bal (1970) and the experimental work of Deleporte (1987) established that some species fed actively on leaf litter. The "small diptera larvae" observed by Zachariae (1965) to feed on litter between the $\mathrm{L}$ and the $\mathrm{F}$ layers belonged probably also to the same family, which we observed to be very common in acid soils, especially in acid mull or weak moder humus. Further discussion of the present results is impossible, since the species which was found had not been identified. Only other work is numerous papers on the damages sciarid larvae cause to mushrooms beds.

\section{Earthworms}

Food diet of the species Dendrobaena octaedra was traced only through its faeces. This animal did not seem to chose between the available food resources and, apart from comminution, no transformation of plant and fungal material occurred during the intestinal transit time. Ingestion of leaves by earthworm species has been recorded many times, but the impact of these animals on the litter they commonly eat in forests has been very poorly studied. Rafidison (1982) compared the ultrastructure of the plant material (beach leaves) before and after ingestion by the anecic worm Nicodrilus velox (Bouché, 1967) and found that the action of the worm on plant cell walls, apart from comminution, seemed to be negligible, except in the case of beech leaves which had been previously decayed by white-rot fungi, similar to our results on an epigeous species. The same author detected a strong modification of the tannin-protein complexes, which was not possible to assess with our techniques, and it must be noticed that he observed a contact between beech leaves and soil bacteria, which was only possible in the gut of such a soil-dwelling species. 
The food diet and digestion of some free-living nematodes has been studied by mean of transmission electron microscopy (Arpin and Kilbertus, 1981; Saur and Arpin, 1989). These authors accounted for the importance of bacteria in the food diet of predatory species belonging to the family Mononchidae and Saur and Arpin (1989) followed the digestive process by comparing different parts of the same intestine, as in our study. Thus our results were in fairly good agreement with theirs.

\section{ACKNOWLEDGEMENTS}

The author is gratefully indebted to Dr. P.M. Latter (Institute of Terrestrial Ecology, Merlewood, England) and Dr. J.M. Anderson (University of Exeter, England) for revising of the English language.

\section{REFERENCES}

Anderson, J.M., 1975. Succession, diversity and trophic relationships of some soil animals in decomposing leaf litter. J. Anim. Ecol., 44: 475-495.

Anderson, J.M., 1978. Competition between two unrelated species of soil Cryptostigmata (Acari) in experimental microcosms. J. Anim. Ecol., 47: 787-803.

Arpin, P. and Kilbertus, G., 1981. Ultrastructure du contenu digestif et de l'épithélium intestinal chez quelques nématodes prédateurs (Mononchida) et bactériophages. Rev. Nématol., 4: 131-143.

Babel, U., 1971. Gliederung und Beschreibung des Humusprofils in mitteleuropäschen Wäldern. Geoderma, 5: 297-324.

Babel, U., 1975. Micromorphology of soil organic matter. In: J.E. Gieseking (Editor), Soil Components. I. Organic Components. Springer, Berlin, pp. 369-473.

Bal, L., 1970. Morphological investigation in two moder-humus profiles and the role of the soil fauna in their genesis. Geoderma, 4: 5-36.

Bal, L., 1982. Zoological Ripening ofSoils. PUDOC, Wageningen, 365 pp. 
Behan-Pelletier, V.M. and Hill, S.B., 1983. Feeding habits of sixteen species of Oribatei (Acari) from an acid peat bog, Glenamoy, Ireland. Rev. Ecol. Biol. Sol, 20: 221-267.

Bengtsson, G., Erlandsson, A. and Rundgren, S., 1988. Fungal odour attracts soil Collembola. Soil Biol. Biochem., 20: 25-30.

Bödvarsson, H., 1970. Alimentary studies of seven common soil-inhabiting Collembola of southern Sweden. Entomol. Scand., 1: 74-80.

Cromack, Jr., K., Sollins, P., Todd, R.D., Crossley, Jr., D.A., Fender, W.M., Fogel, R. and Todd, A.W., 1977. Soil microorganism-arthropod interactions: fungi as major calcium and sodium sources. In: W.J. Mattson (Editor), The Role of Arthropods in Forest Ecosystems. Springer, New York, pp. 78-84.

Deleporte, S., 1987. Rôle du Diptère Sciaridae Bradysia conjinis (Winn., Frey) dans la dégradation d'une litière de feuillus. Rev. Ecol. Biol. Sol, 24: 341-858.

Dinsdale, D., 1974. The digestive activity ofa phthiracarid mite mesenteron. J. Insect Physiol., 20: 2247-2260.

Esau, K., 1965. Plant Anatomy, 2nd ed. Wiley, New York, 767 pp.

Frankland, J.C., 1974. Importance of phase-contrast microscopy for estimation of total fungal biomass by the agar-film technique. Soil Biol. Biochem., 6: 409-410.

Gilmore, S.K. and Raffensperger, E.M., 1970. Foods ingested by Tomocerus spp. (Collembola, Entomobryidae), in relation to habitat. Pedobiologia, 10: 135-140.

Gochenaur, S.E., 1987. Evidence suggests that grazing regulates ascospore density in soil. Mycologia, 79: $445-450$.

Hågvar, S. and Kjøndal, B.R., 1981. Succession, diversity and feeding habits of microarthropods in decomposing birch leaves. Pedobiologia, 22: 385-408.

Handley, W.R.C., 1954. Mull and mor formation in relation to forest soils. Bull. No. 23, Forestry Commission, London, II 5 pp. +14 inset plates.

Hanlon, R.D.G., 1981. Influence of grazing by Collembola on the activity of senescent fungal colonies grown on media of different nutrient concentration. Oikos, 36: 362-367. 
Haq, M.A., 1981. Feeding habits of ten species of oribatid mites (Acari: Oribatei) from Malabar, South India. Ind. J. Acarology, 6: 39-50.

Hartenstein, R., 1962a. Soil Oribatei. I. Feeding specificity among forest soil Oribatei. Ann. Entomol. Soc. Am., 55: 202-206.

Hartenstein, R., 1962b. Soil Oribatei. VI. Protoribates lophotrichus (Acarina: Haplozetidae) and its association with microorganisms. Ann. Entomol. Soc. Am., 55: 587-591.

Hassall, M., Visser, S. and Parkinson, D., 1983. Vertical migration of Onychiurus subtenuis in relation to rainfall and microbial activity. In: P. Lebrun et al. (Editors), New Trends in Soil Biology. Proc. 8th Int. Colloquium of Soil Zoology, Louvain-la-Neuve, Belgium, 30/VIII-2/IX, 1982. Université catholique de Louvain, Louvain-la-Neuve, Belgium, 612 pp.

Hayes, A.J., 1963. Studies on the feeding preferences of some phthiracarid mites (Acari: Oribatidae). Entomol. Exp. Appl., 6: 241-256.

Healey, I.N. and Russell-Smith, A., 1971. Abundance and feeding preferences of fly larvae in two woodland soils. In: Organismes du Sol et Production Primaire. Proc. 4th Colloquium Pedobiologiae, Dijon, France, 14/IX-19/IX, 1970. INRA, Paris, pp. 177-191.

Jacot, A.P., 1939. Reduction of spruce and fir litter by minute animals. J. Forest., 37: 858-860.

Kendrick, W.B. and Burges, A., 1962. Biological aspects of the decay of Pinus sylvestris leaf litter. Nova Hedwig., 4: 313-344 + 14 inset plates.

Kilbertus, G. and Vannier, G., 1979. Microbial analysis and weight estimation of feces produced by four sympatric Colembola species in forest litter. Rev. Ecol. Biol. Sol, 16: 169-180.

Kilbertus, G. and Vannier, G., 1981. Relations microflore-microfaune dans la grotte de Sainte-Catherine (Pyrénées ariégeoises). II. Le régime alimentaire de Tomocerus minor (Lubbock) et Tomocerus problematicus Cassagnau (Insectes Collemboles). Rev. Ecol. Biol. Sol, 18: 319-338.

Knight, C.B. and Angel, R.A., 1967. A preliminary study of the dietary requirements of Tomocerus (Collembola). Am. Midl. Nat., 77: 510-517. 
Kretzschmar, A., 1987. Caractérisation microscopique de l'activité des lombriciens endogés. In: N. Fedoroff, L.M. Bresson and M.A. Courty (Editors), Micromorphologie des Sols (Soil Micromorphology). Proc. 7th Int. Working Meeting on Soil Micromorphology, Paris, France, VII 1985. AFES, Paris, pp. $325-330$.

Kubiëna, W., 1943. L'investigation microscopique de l'humus (Die mikroskopische Humusuntersuchung). Z. Weltforstwirtsch., 10: 387-410.

Kubiëna, W.L., 1953. The Soils of Europe. Illustrated Diagnosis and Systematics. CSIC, Madrid and Thomas Murby and Company, London, 318 pp. +25 inset plates.

Kubiëna, W.L., 1955. Animal activity in soil as a decisive factor in establishment of humus forms. In: D.K. McE. Kevan (Editor), Soil Zoology, Proc. University of Nottingham Second Easter School in Agricultural Science, 1955. Butterworths, London, pp. 73-82+ 2 inset plates.

Kubíková, J. and Rusek, J., 1976. Development of Xerothermic Rendzinas. A Study in Ecology and Soil Microstructure. Academia, Prague, 78 pp. +16 inset plates.

Latter, P.M., 1977. Decomposition of a moorland litter, in relation to Marasmius androsaceus and soil fauna. Pedobiologia, 17: 418-427.

Latter, P.M. and Howson, G., 1978. Studies on the microfauna of blanket bog with particular reference to Enchytraeidae. II. Growth and surviva1 of Cognettia sphagnetorum on various substrates. J. Anim. Ecol., 47: 425-448.

Luxton, M., 1972. Studies on the oribatid mites of a Danish beech wood soil. I. Nutritional biology. Pedobiologia, 12: 434-463.

Macfadyen, A., 1963. The contribution of the microfauna to total soil metabolism. In: J. Doeksen and J. Van der Drift (Editors), Soil Organisms. Proc. Colloq. on Soil Fauna, Soil Microflora and their Relationships, held at Oosterbeèk, Netherlands, 10/IZ-16/IX, 1962. North-Holland, Amsterdam, pp. 3-17.

Marshall, V.G., 1978. Gut content analysis of the Collembolan Bourletiella hortensis (Fitch) from a forest nursery. Rev. Ecol. Biol. Sol, 15: 243-250.

McMillan, J.H. and Healey, I.N., 1971. A quantitative technique for the analysis of the gut contents of 
Collembola. Rev. Ecol. et Biol. Sol, 8: 295-300.

Mitchell, M.J. and Parkinson, O., 1976. Fungal feeding of oribatid mites (Acari: Cryptostigmata) in an aspen woodland soil. Ecology, 57: 302-312.

Pande, Y.D. and Berthet, P., 1973. Studies on the food and feeding habits of soil Oribatei in a black pine plantation. Oecologia (Berlin), 12: 413-426.

Ponge, J.F., 1984. Etude écologique d'un humus forestier par l'observation d'un petit volume, premiers résultats. I. La couche $\mathrm{L}_{1}$ d'un moder sous pin sylvestre. Rev. Ecol. Biol. Sol, 21: 161-187.

Ponge, J.F., 1985a. Etude écologique d'un humus forestier par l'observation d'un petit volume. II. La couche $\mathrm{L}_{2}$ d'un moder sous Pinus sylvestris. Pedobiologia, 28: 73-114.

Ponge, J.F., 1985b. Utilisation de la micromorphologie pour l'étude des relations trophiques dans le sol: la couche L d'un moder hydromorphe sous Pinus sylvestris (Forêt d'Orléans, France). Bull. Ecol., 16: $117-132$.

Ponge, J.F., 1988. Etude écologique d'un humus forestier par l'observation d'un petit volume. III. La couche $\mathrm{F}_{1}$ d'un moder sous Pinus sylvestris. Pedobiologia, 31: 1-64.

Ponge, J.F., 1990. Ecological study of a forest humus by observing a small volume. IV. Penetration of litter by mycorrhizal fungi. Eur. J. Forest Pathol., 20: 290-303.

Ponge, J.F., in prep. Succession of organisms during decomposition of needles in a small area of Scots pine litter.

Ponge, J.F. and Charpentié, M.J., 1981. Etude des relations microflore-microfaune: expériences sur Pseudosinella alba (Packard), Collembole mycophage. Rev. Ecol. Biol. Sol, 18: 291-303.

Poole, T.B., 1959. Studies on the food of Collembola in a Douglas fir plantation. Proc. Zool. Soc. London, 132: $71-82$.

Rafidison, G.Z., 1982. Rôle de la faune dans l'humification: transformations des feuilles de hêtre par un ver anécique (Nicodrilus velox). Doctorate Thesis, 112 pp., unpublished.

Rusek, J., 1975. Die bodenbildende Funktion von Collembolen und Acarina. Pedobiologia, 15: 299-308. 
Saur, E. and Arpin, P., 1989. Ultrastructural analysis of the intestinal contents of Clarkus papillatus (Nemata: Mononchina): ecological interest of the survey. Rev. Nématol., 12: 413-422.

Saur, E. and Ponge, J.F., 1988. Alimentary studies on the Collembolan Paratullbergia callipygos using transmission electron microscopy. Pedobiologia, 31: 355-379.

Shaw, P.J.A., 1988. A consistent hierarchy in the fungal preferences of the Collembola Onychiurus armatus. Pedobiologia, 31: 179-187.

Springett, J.A., 1970. The distribution of life histories of some moorland Enchytraeidae (Oligochaeta). J. Anim. Ecol., 39: 725-737.

Standen, V. and Latter, P.M., 1977. Distribution of a population of Cognettia sphagnetorum (Enchytraeidae) in relation to micro habitats in a blanket bog. J. Anim. Ecol., 46: 213-229.

Stefaniak, O. and Seniczak, S., 1983. Intestinal microflora in representatives of different feeding groups of soil moss mites (Acarida, Oribatida). In: P. Lebrun et al. (Editors), New Trends in Soil Biology. Proc. 8th Int. Colloquium of Soil Zoology, Louvain-la-Neuve, Belgium, 30/VIII-2/IX, 1982. Université catholique de Louvain, Louvain-la-Neuve, Belgium, pp. 622-624.

Toutain, F., 1981. Les humus forestiers. Structures et modes de fonctionnement. Rev. Forest. Fran., 33: 449-477.

Toutain, F., Villemin, G., Albrecht, A. and Reisinger, O., 1982. Etude ultrastructurale des processus de biodégradation. II. Modèle enchytraeides-litière de feuillus. Pedobiologia, 23: 145-156.

Ulber, B., 1983. Einfluss von Onychiurus fimatus Gisin (Collembola, Onychiuridae) und Folsomia fimetaria (L.) (Collembola, Isotomidae) auf Pythium ultimum Trow., einen Erregerdes Wurzelbrandes der Zuckerrübe. In: P. Lebrun et al. (Editors), New Trends in Soil Biology. Proc. 8th Int. Colloquium of Soil Zoology, Louvain-la-Neuve, Belgium, 30/VIII-2/IX, 1982. Université catholique de Louvain, Louvain-la-Neuve, Belgium, pp. 261-268.

Vegter, J.J., 1983. Food and habitat specialization in coexisting springtails (Collembola, Entomobryidae). Pedobiologia, 25: 253-262.

Verhoef, H.A., Prast, J.E. and Verweij, R.A., 1988. Relative importance of fungi and algae in the diet and 
nitrogen nutrition of Orchesella cincta (L.) and Tomocerus minor (Lubbock) (Collembola). Functional Ecol., 2: 195-201.

Visser, S., Whittaker, J.B. and Parkinson, D., 1981. Effects of collembolan grazing on nutrient release and respiration of a leaf litter inhabiting fungus. Soil Biol. Biochem., 13: 215-218.

Warnock, A.J., Fitter, A.H. and Usher, M.B., 1982. The influence of a springtail, Folsomia candida (Insecta, Collembola), on the mycorrhizal association of leek, Allium parum, and the vesicular-arbuscular mycorrhizal endophyte, Glomus fasciculatus. New Phytol., 90: 285-292.

Wolters, V., 1988. Effects of Mesenchytraeus glandulosus (Oligochaeta, Enchytraeidae) on decomposition processes. Pedobiologia, 32: 387-398.

Zachariae, G., 1965. Spuren tierischer Tätigkeit im Boden des Buchenwaldes. Forstwissensch. Forsch., 20: 68 pp. 


\section{Legends of figures}

Fig. 1. Population density and bio-volume (upper estimate, see text) of the five main mesofaunal groups in the $\mathrm{L}_{1}, \mathrm{~L}_{2}$ and $\mathrm{F}_{1}$ layers.

Fig. 2. Oribatid faecal pellets at the inside of a pine needle (after partial dissection). $F_{1}$ layer.

Fig. 3. Two enchytraeid worms (Cognettia sphagnetorum) tunnelling through the same pine needle, indicated by arrows (pellets have been deposited at the outside). $\mathrm{F}_{1}$ layer.

Fig. 4. Protoxylem reticulate tracheid (arrow 1) and dissociated cell walls (arrow 2) from pine needles in the gut of an enchytraeid worm. Same species as above. $\mathrm{L}_{2}$ layer. Phase contrast. Bar=50 $\mu \mathrm{m}$.

Fig. 5. Accumulation of bordered pits (arrow 1) from pine transfusion tissue (stele parenchyma of needles) and emptied basidiomycete hyphae (arrow 2) in the gut of an enchytraeid worm. Same species as above $F_{1}$ layer. Phase contrast. Bar $=50 \mu \mathrm{m}$.

Fig. 6. Faecal pellet, attributed to a woodlouse. Pine needles, cutted into small pieces and compacted. $F_{1}$ layer.

Fig. 7. Faecal material, attributed to a slug. Pine needles, ingested as entire or large pieces. $\mathrm{F}_{1}$ layer.

Fig. 8. Pine needle mesophyll in the abovementioned faecal material. Cells have their wall intact, but their content has disappeared. $F_{1}$ layer. Phase contrast. $B a r=50 \mu \mathrm{m}$.

Fig. 9. Resin pieces in the gut of the enchytreid worm Cognettia sphagnetorum. $\mathrm{L}_{2}$ layer. Phase contrast. Bar= $50 \mu \mathrm{m}$.

Fig. 10. Two pine pollen grains (exin) in the gut of the same species. $L_{1}$ layer. Phase contrast. Bar=50 $\mu \mathrm{m}$.

Fig. 11. Fragment of a pine pollen grain (exin, arrow 1), together with fungal wall remnants (arrow 2) and bacteria in the gut of the same species. $\mathrm{L}_{2}$ layer. Phase contrast. $\mathrm{Bar}=50 \mu \mathrm{m}$.

Fig. 12. Pine pollen grain (exin) in the gut of a sciarid larva. $L_{1}$ layer. Phase contrast. Bar= $50 \mu \mathrm{m}$.

Fig. 13. Hyaline hyphae partially digested in the gut of the enchytraeid worm Cognettia sphagnetorum. Compare with intact cell walls of the mycorrhizal fungus Cenococcum geophilum (arrow). $\mathrm{L}_{2}$ 1ayer. Phase 
contrast. Bar $=50 \mu \mathrm{m}$.

Fig. 14. Hyphae of two mycorrhizal fungi, Cenococcum geophilum (melanized walls, arrow 1) and Hyphodontia sp. (hyaline hyphae, arrow 2) in the gut of the springtail Pseudosinella terricola. Only the hyaline hyphae were being digested. $\mathrm{F}_{1}$ layer. Phase contrast. Bar $=50 \mu \mathrm{m}$.

Fig. 15. Hyaline hyphae of the mycorrhizal fungus Hyphodontia sp., with intact cell walls (arrow), in the gut of a sciarid larva. $\mathrm{L}_{2}$ layer. Phase contrast. Bar $=50 \mu \mathrm{m}$.

Fig. 16. Me1anized hyphae of the mycorrhiza1 fungus Cenococcum geophilum, with intact cell walls, in the gut of the enchytraeid worm Cognettia sphagnetorum. $\mathrm{L}_{1}$ layer. Phase contrast. Bar=50 $\mu \mathrm{m}$.

Fig. 17. Same material in the same animal species as above. Note small holes (arrows) in elsewhere intact cell walls. $\mathrm{L}_{2}$ layer. Phase contrast. Bar= $50 \mu \mathrm{m}$.

Fig. 18. Melanized hyphae, with intact cell walls, of the mycorrhizal fungus Cenococcum geophilum, in an oribatid faecal pellet. $\mathrm{L}_{2}$ 1ayer. Phase contrast. Bar= $50 \mu \mathrm{m}$.

Fig. 19. Filamentous cyanobacteria du ring their digestion in the gut of the enchytraeid worm Cognettia sphagnetorum. Cells (arrows) have been separated and emptied. In other respects same as Fig. 18.

Fig. 20. Chlorella-like algae in the gut of the same species. Intact cells, with opaque cytoplasm. In other respects same as Fig. 18.

Fig. 21. Digestion of Chlorella-like algae in the gut of the same species. Covering of the cells with symbiotic bacteria (1) was followed by loss of cytoplasm opacity (2) then by collapsing (3). $\mathrm{L}_{2}$ layer. Phase contrast. Bar $=50 \mu \mathrm{m}$.

Fig. 22. Soil algae, without cell contents, in the gut of the springtail Lepidocyrtus lanuginosus. $\mathrm{F}_{1}$ layer. Phase contrast. Bar $=50 \mu \mathrm{m}$.

Fig. 23. Soil bacteria together with some minute particles in the food bolus of the springtail Megalothorax minimus. In other respects same as Fig. 22.

Fig. 24.Two oribatid faeces (arrows) in the gut of the enchytraeid worm Cognettia sphagnetorum. In other respects same as Fig. 22. 
Fig. 25. Associated bacteria (right) near the food bolus (left) in the gut of the oribatid mite Platynothrus peltifer. $\mathrm{L}_{2}$ layer. Phase contrast. Bar $=50 \mu \mathrm{m}$. 
TABLE 1 Food resources and their ingestion by animal groups.

\begin{tabular}{|c|c|c|c|c|c|c|c|c|}
\hline \multirow[t]{2}{*}{ Food } & \multirow[t]{2}{*}{ Enchytraeids } & \multirow[t]{2}{*}{ Sciarids } & \multicolumn{2}{|c|}{ Oribatids } & \multirow[t]{2}{*}{ Springtails } & \multirow[t]{2}{*}{ Earthworms } & \multirow[t]{2}{*}{ Woodlice } & \multirow[t]{2}{*}{ Slugs } \\
\hline & & & Phthir. & Others & & & & \\
\hline Pine needles & $*$ & $*(\mathrm{D})$ & $*(\mathrm{~T})$ & & & $*$ & $*$ & $*$ \\
\hline Pine resin & $*$ & & & & & & & \\
\hline Pine pollen & $*(\mathrm{D})$ & $*$ & & & & $*$ & & \\
\hline Pine wood & $*$ & & & & & & & \\
\hline Pine bark & & & $*$ & & & & & \\
\hline Bracken & $*$ & & & & & & & \\
\hline Moss living & $*$ & $*$ & & & & & & \\
\hline Moss dead & $*$ & & & & & & & \\
\hline Fungus hyaline & $*(\mathrm{D})$ & $*$ & & $*(\mathrm{D})$ & $*$ & & & \\
\hline Fungus dematiaceous & $*$ & & & $*(\mathrm{~T})$ & & & & \\
\hline Cyanobacteria & $*$ & & & & & & & \\
\hline Algae & $*(\mathrm{D})$ & & & & $*$ & & & \\
\hline Bacteria & & & & & $*$ & & & \\
\hline Faeces & $*$ & & $*$ & & $*$ & $*$ & & \\
\hline Testacea & $*(\mathrm{D})$ & & & & & & & \\
\hline
\end{tabular}

* = Ingested; $\mathrm{D}=$ digested; $\mathrm{T}=$ transformed 


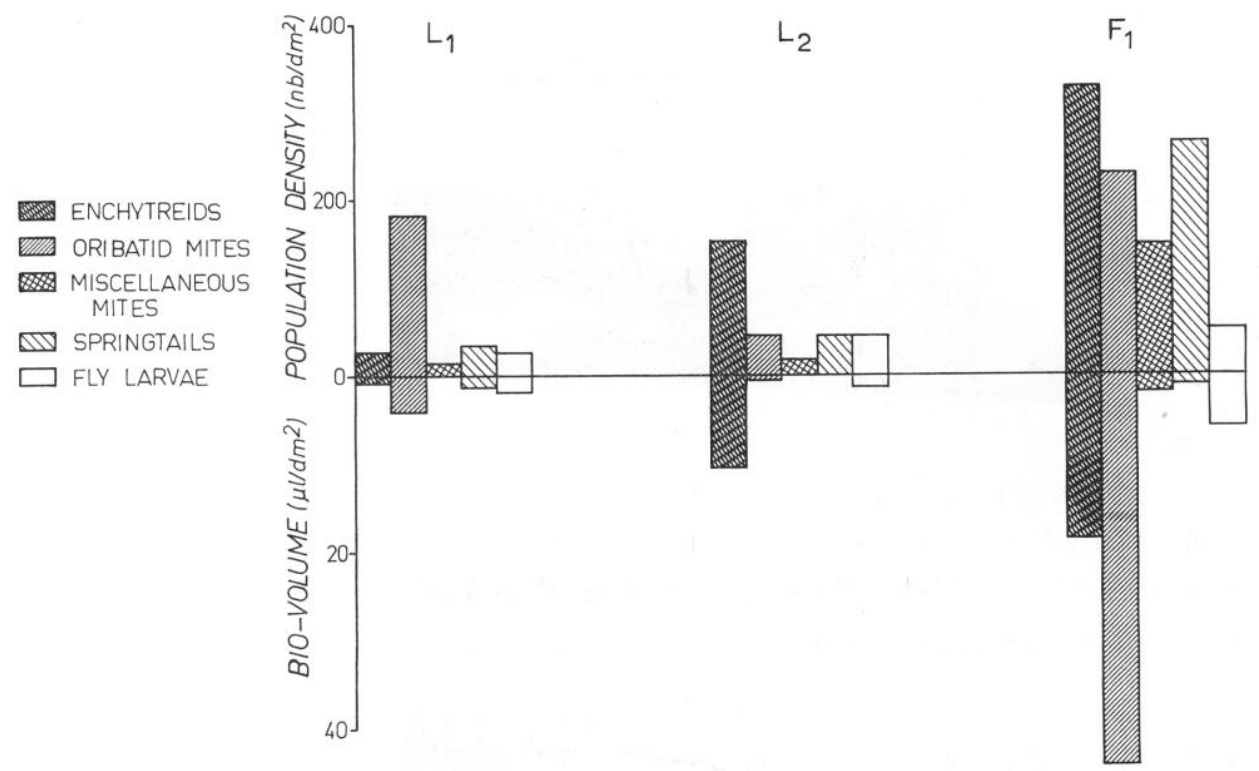

Fig. 1 
$2 \mathrm{~m} \mathrm{~m}$

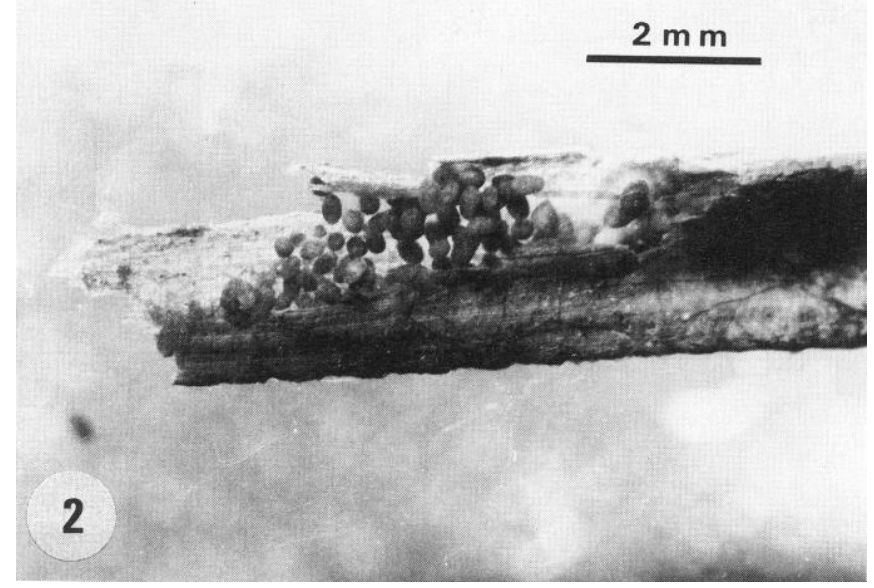

Fig. 2 


$$
D
$$




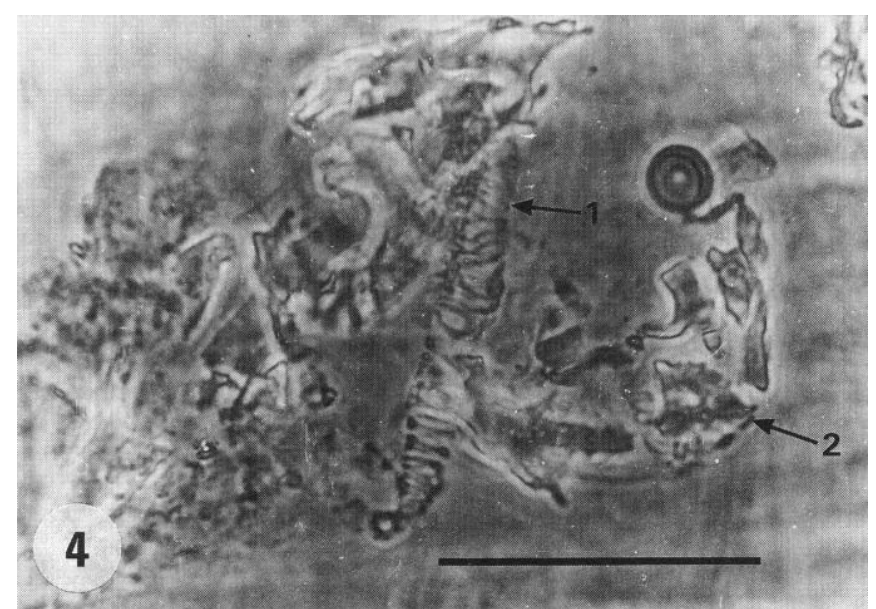

Fig. 4 


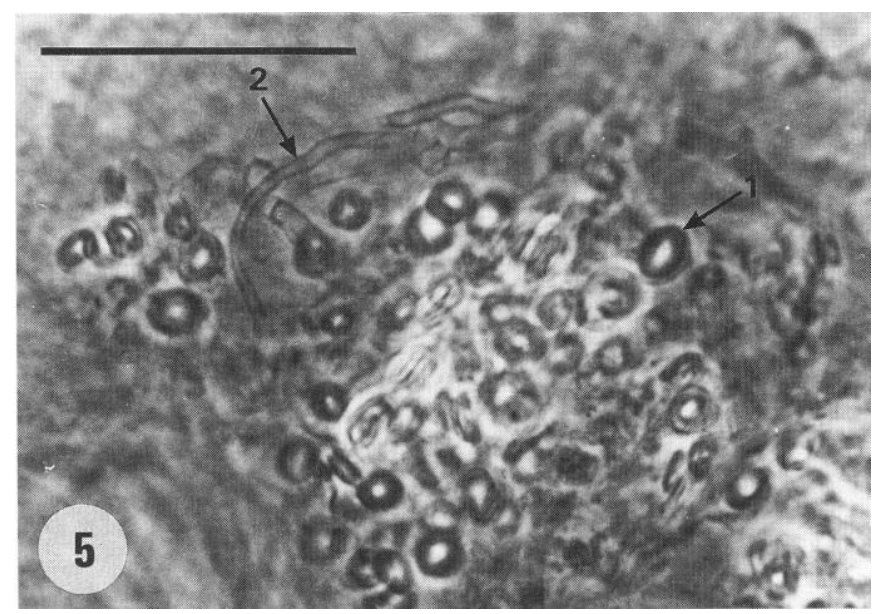

Fig. 5 


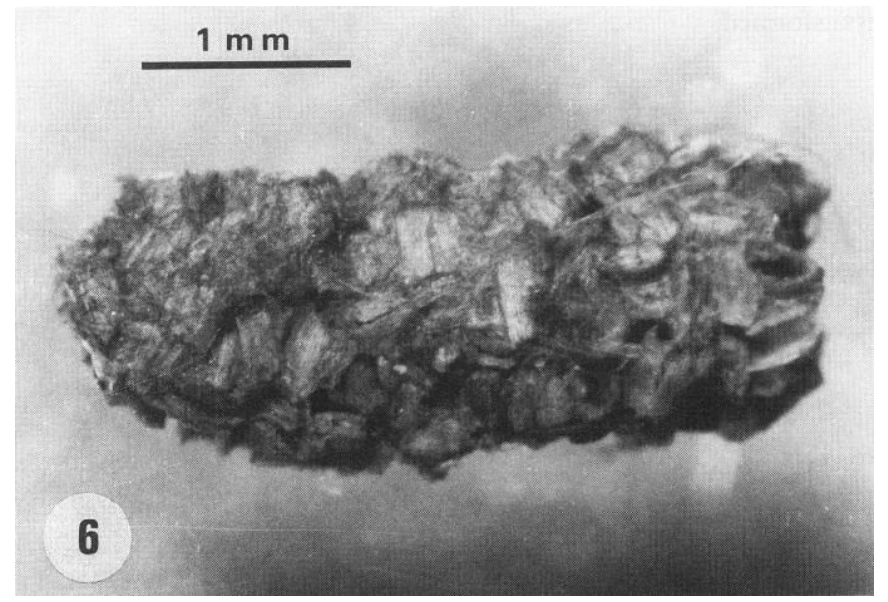

Fig. 6 


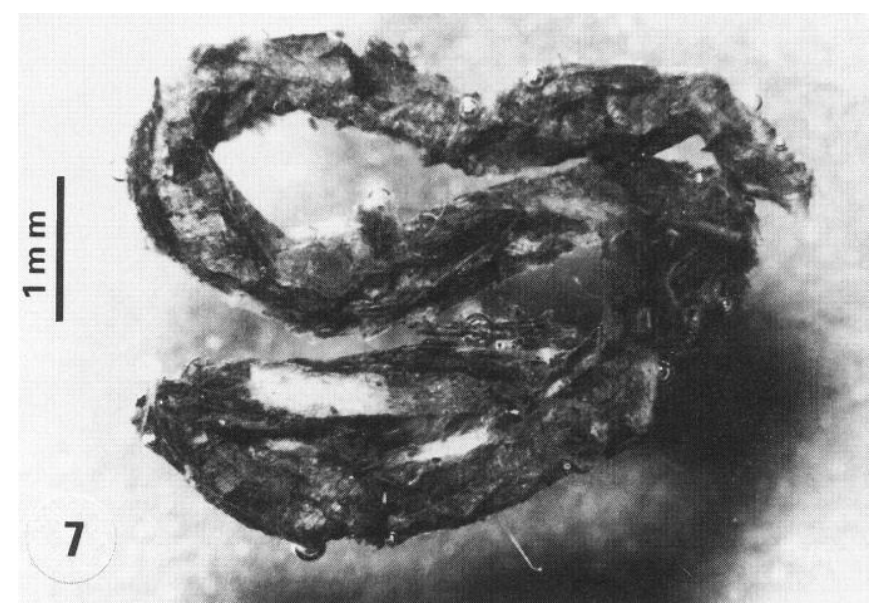

Fig. 7 


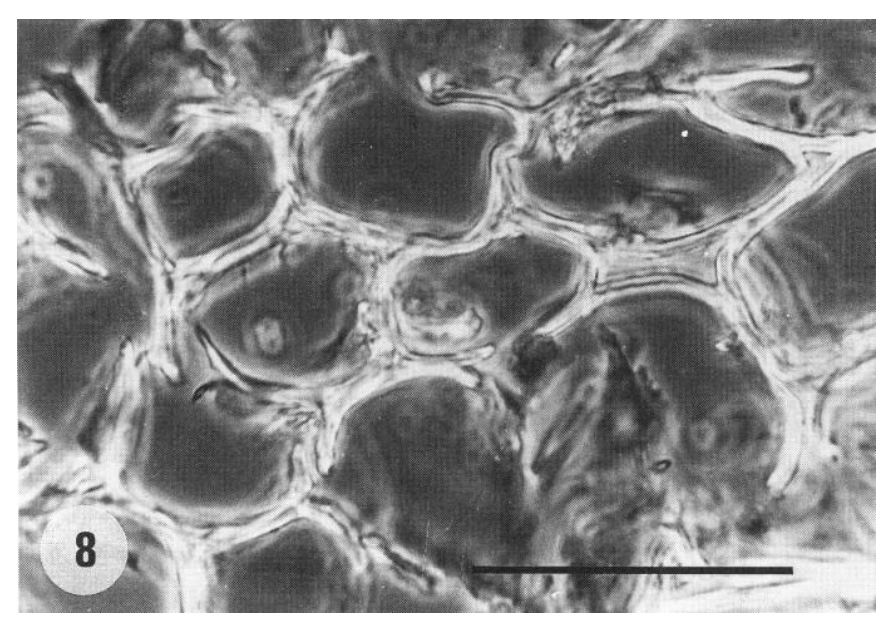

Fig. 8 


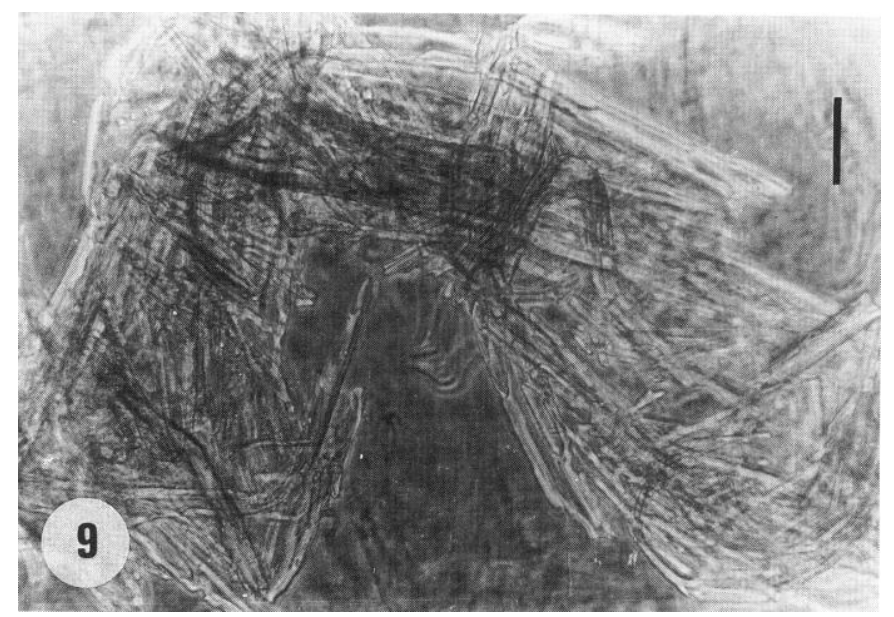

Fig. 9 


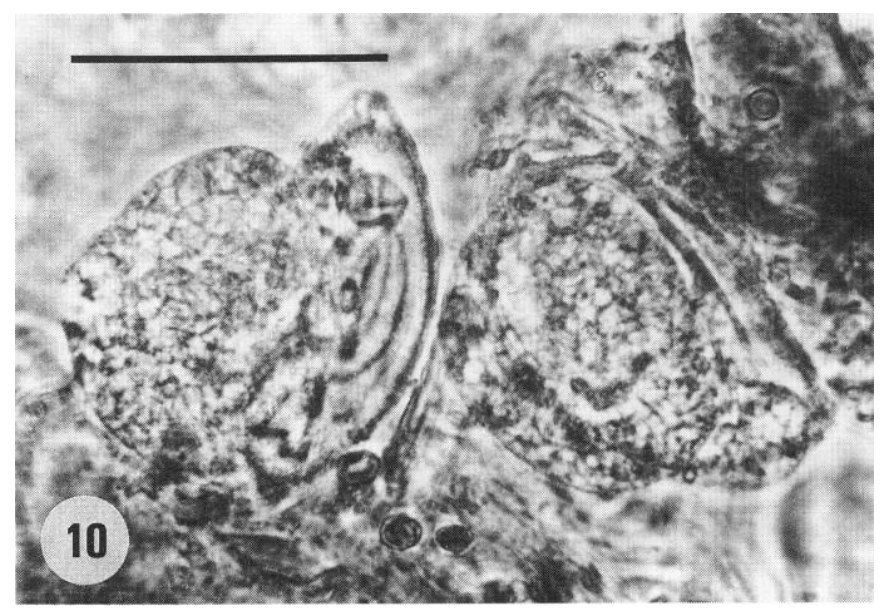

Fig. 10 


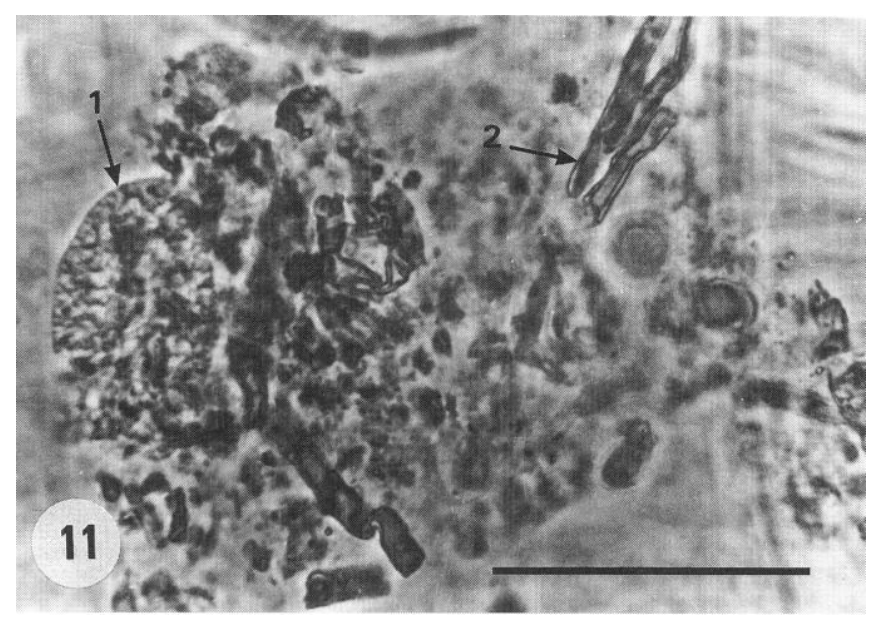

Fig. 11 


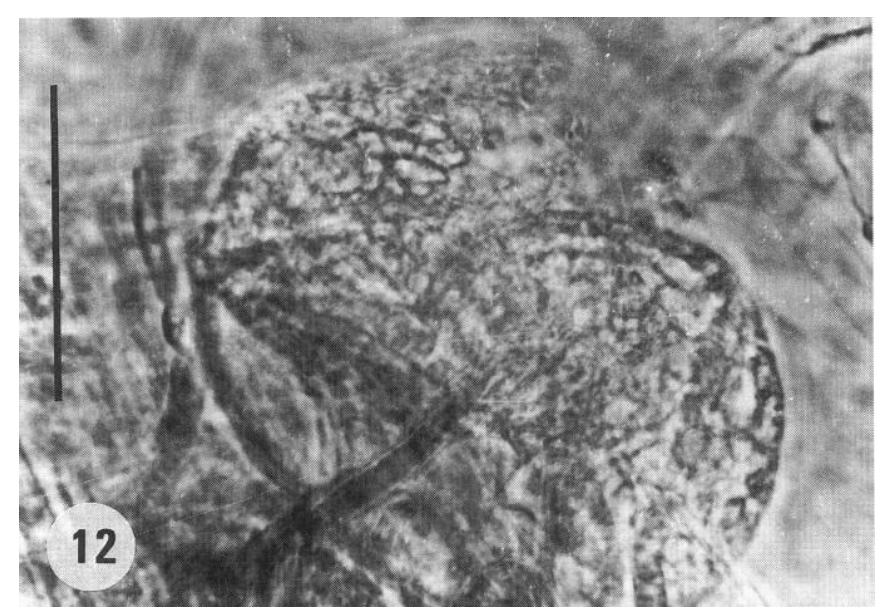

Fig. 12 


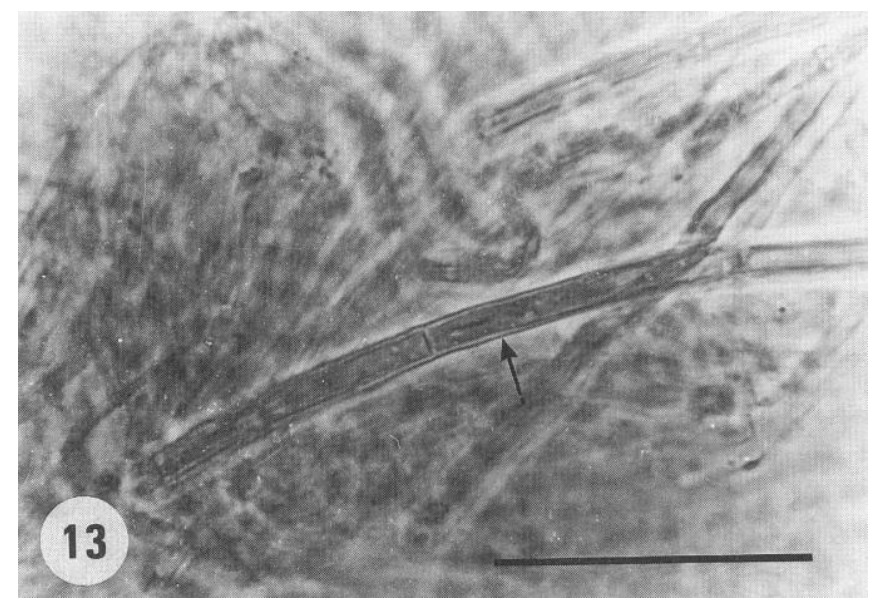

Fig. 13 


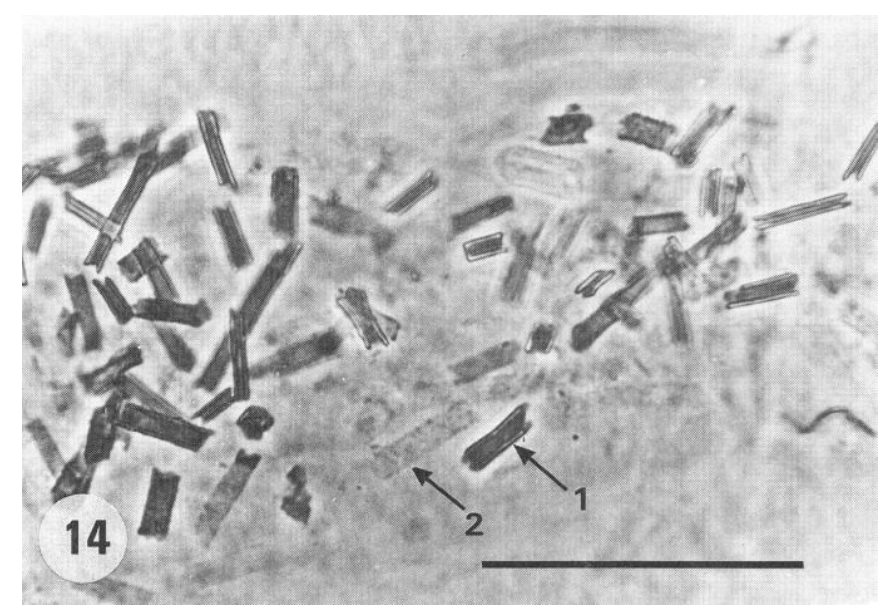

Fig. 14 


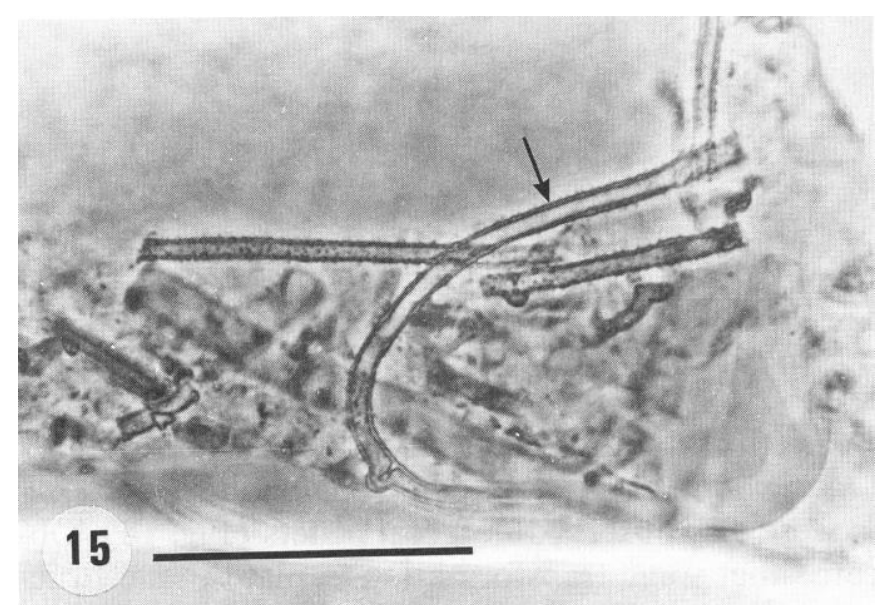

Fig. 15 


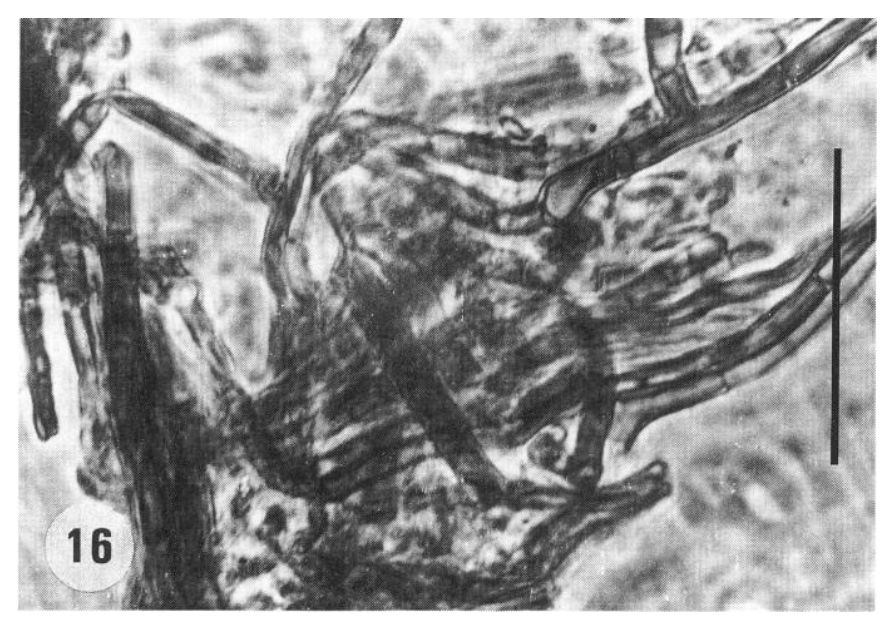

Fig. 16 


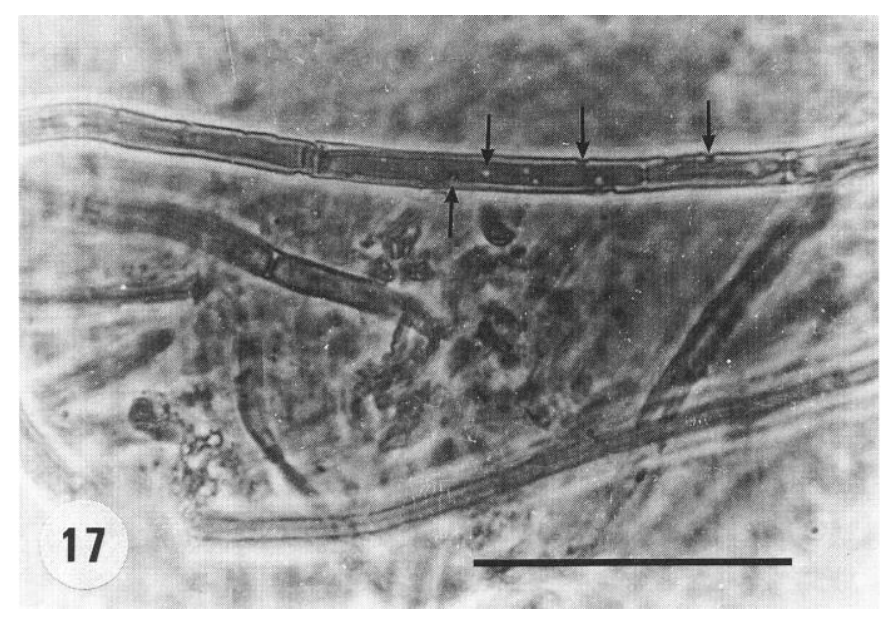

Fig. 17 


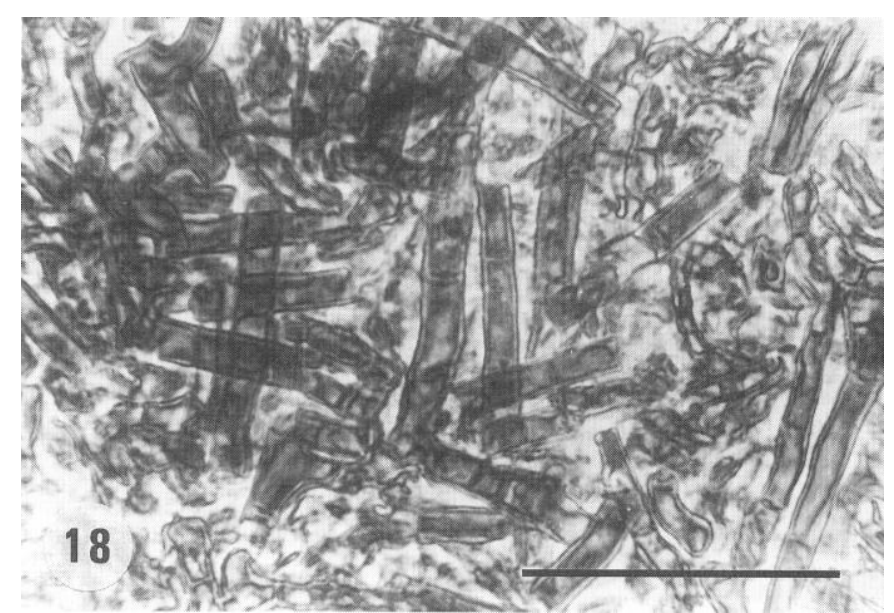

Fig. 18 


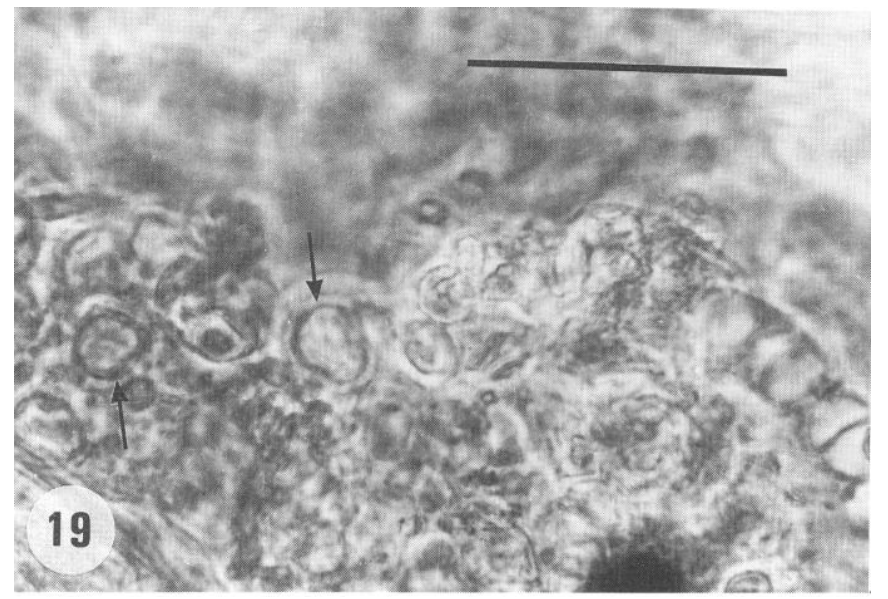

Fig. 19 


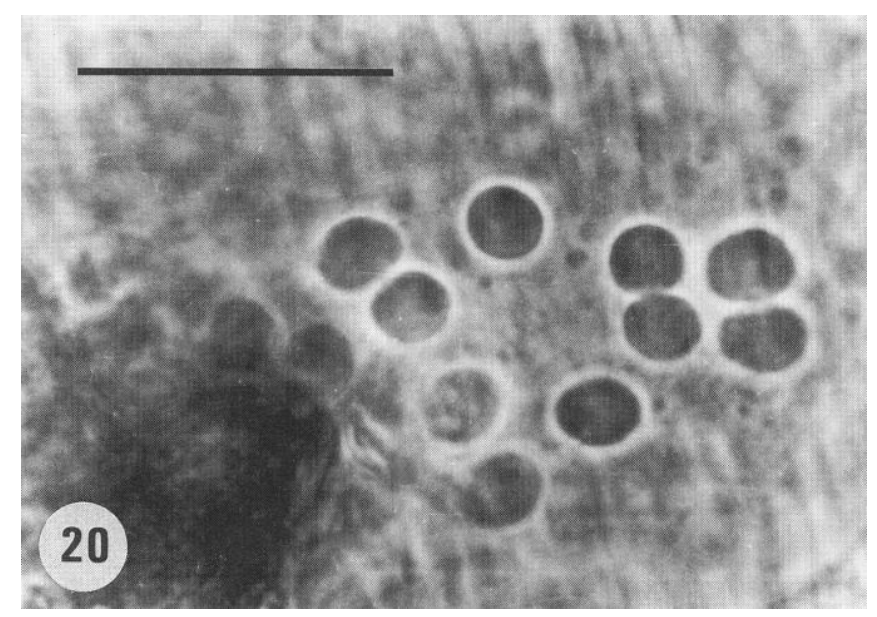

Fig. 20 


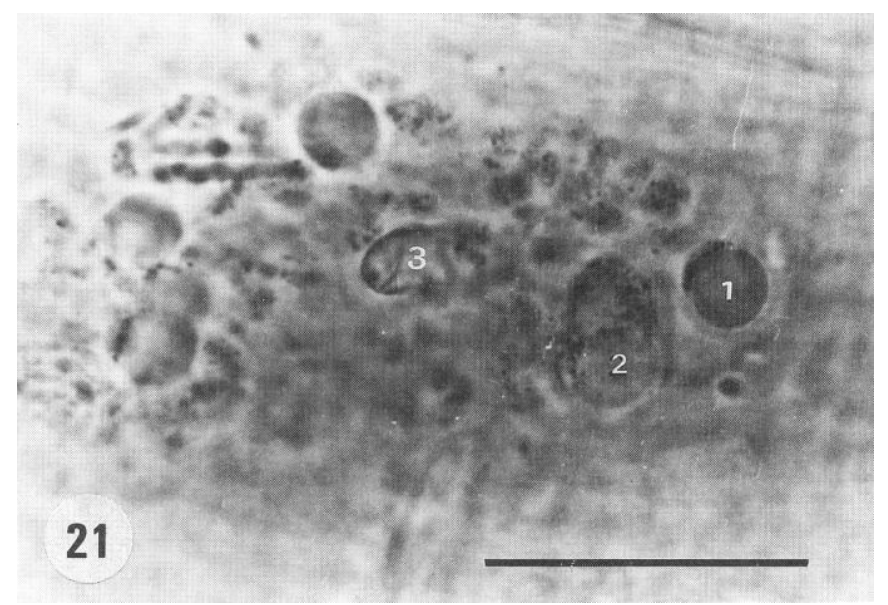

Fig. 21 


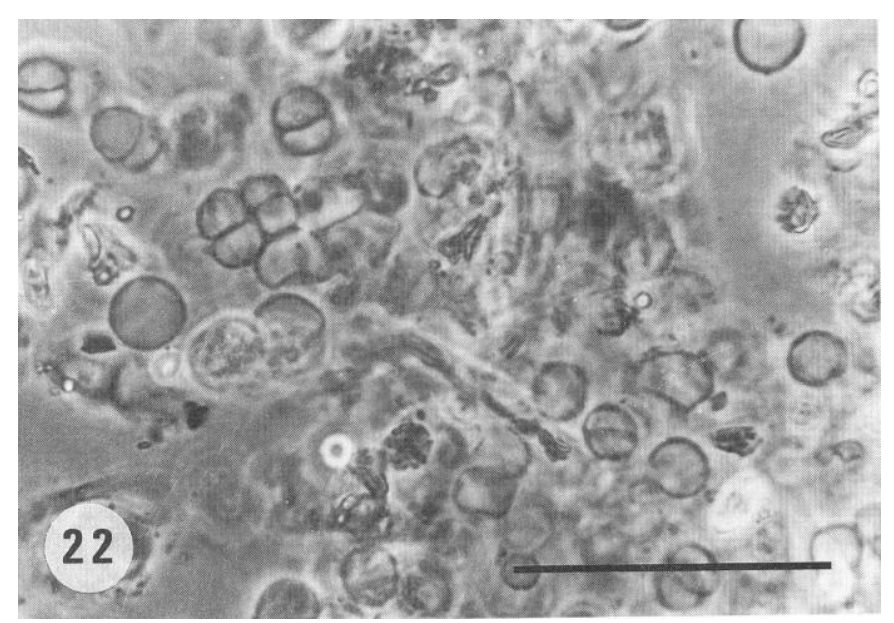

Fig. 22 


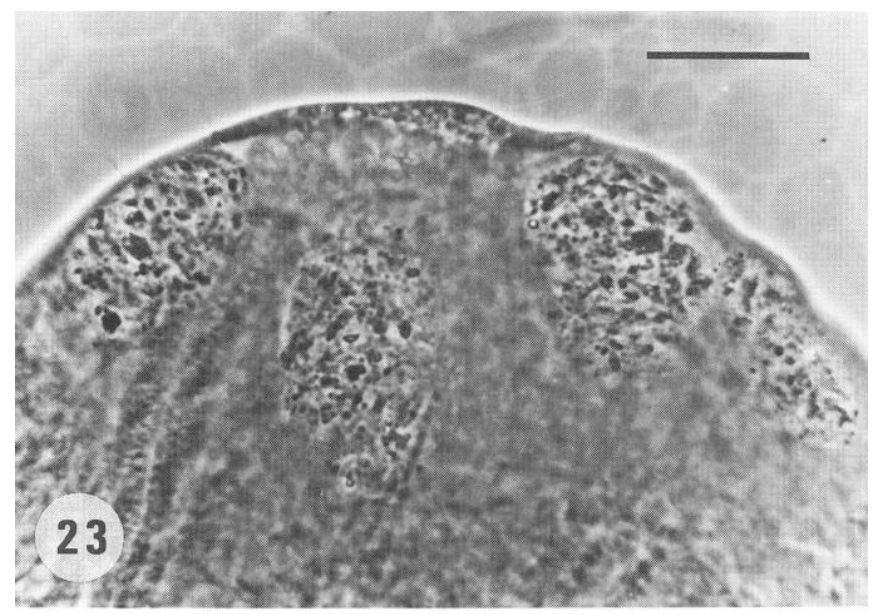

Fig. 23 


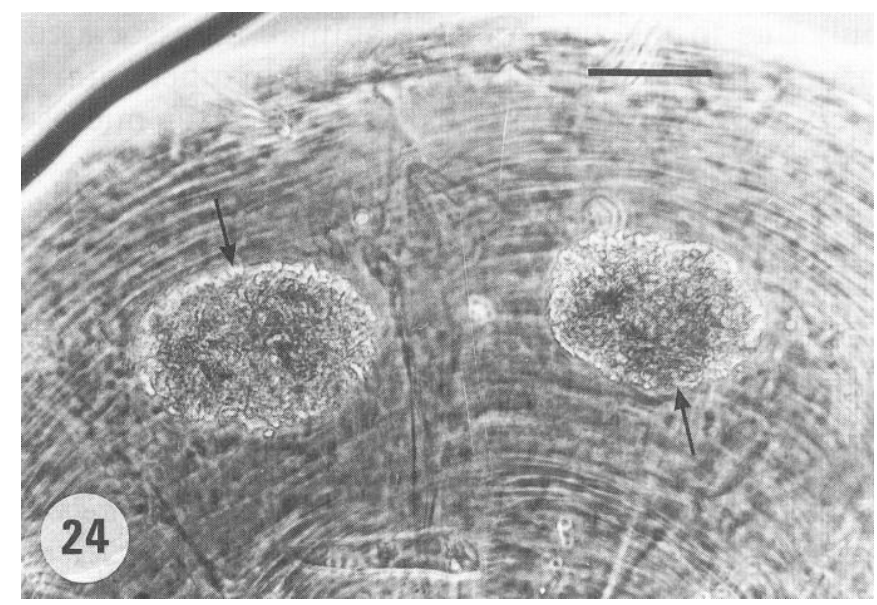

Fig. 24 


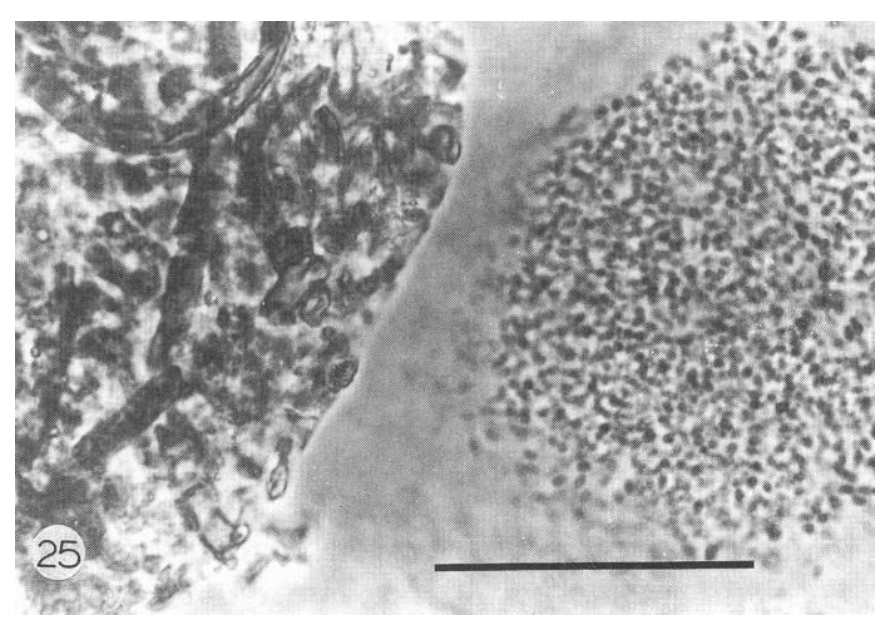

Fig. 25 